Олійник Руслан Юрійович аспірант кафедри публічної політики, Навчально-науковий інститут публічного управління та державної служби Київського національного університету імені Тараса Шевченка, вул. Академіка Ромоданова, 12/2, м. Київ, 02000, тел.: (067) 644-74-47, e-mail: oliynyk_r_y@ukr.net, https://orcid.org/0000-0003-4115-1457

\title{
АНАЛІЗ КЛЮЧОВИХ МЕТОДОЛОГІЙ ПРОЄКТНОГО МЕНЕДЖМЕНТУ В ПУБЛІЧНОМУ УПРАВЛІННІ
}

Анотація. У статті викладено результати системного огляду методологій проєктного підходу, які використовуються в організації електронного урядування в публічному управлінні. Необхідність ревізії відповідних методологій пояснюється неоднозначністю їх результативності у публічному секторі, насамперед, країн, що розвиваються. Розкриваються зміст та особливості таких методологічних підходів проєктного менеджменту, як Довідник з управління проєктами (РМBOK), Проєкти в контрольованих середовищах (PRINCE2), модель «Водоспаду» (Waterfall) та «гнучка» модель (Agile). Виявляються сильні та слабкі сторони кожної з цих методологій у публічному контексті. Наголошується на тому, що практика бізнесового сектору у використанні проєктних методологій не може бути автоматично перенесена у публічну площину, натомість, повинна враховувати політичний, управлінський та адміністративний аспекти.

Зазначається, що успішна реалізація проєктів електронного урядування залежить від: підходу, методів та інструментів управління проєктами; моніторингу та оцінки проєктів електронного управління; визначення та управління сферою застосування; ризиків проєкту та пом'якшення тощо.

Проєкти повинні керуватися постійно, коли виникають проблеми, а РМВОК має виходити за межі структурованого та повторюваного процесу у виробничому секторі. Методологія водоспаду передбачає тривалі часові межі без гнучкості у прийнятті вимог на пізніх стадіях розробки. Бізнес-користувач не має можливості переглянути продукт, якщо він повністю не розроблений. PRINCE2 націлений на проєкти, де початок, середина та кінець організовані та контролюються, регулярні огляди прогресу відбуваються відповідно до плану. Відстеження здійснюється на основі бізнес-критеріїв, гнучких пунктів прийняття рішень, автоматичного управлінського контролю за будь-якими відхиленнями від плану, залучення керівництва та зацікавлених сторін у потрібний час та місце під час проєкту, 
хороших каналів комунікації. Agile - це набір гнучких та легших методологій, які залежать від таких принципів, як ітерації з часовими рамками, щоденні зустрічі, постійне вдосконалення тощо.

Окреслюється конструктивний досвід використання різних методологій проєктного менеджменту в електронному урядуванні окремих розвинених держав, зокрема Австралії, США, Швейцарії і т. д.

Ключові слова: методологія, управління проєктами, електронний уряд, публічне управління, модель «водоспаду», «гнучка» модель, моніторинг, ризики.

Oliynyk Ruslan Yuriiovych PhD student of Public Policy Department Educational and Scientific, Institute of Public Administration and Civil Service Taras Shevchenko National University of Kyiv, 12/2, Academician Romodanov St., Kyiv, 02000, tel .: (067) 644-74-47, e-mail: oliynyk_r_y@ukr.net, https://orcid.org/0000-0003-4115-1457

\section{ANALYSIS OF THE MAIN PROJECT MANAGEMENT METHODOLOGIES IN PUBLIC ADMINISTRATION}

Abstract. The article presents the results of a systematic review of project approach methodologies used in the organization of e-government in public administration. The need to revise the relevant methodologies is explained by the ambiguity of their effectiveness in the public sector, especially in developing countries. The content and features of such methodological approaches of project management as the Project Management Body of Knowledge (PMBOK), Projects in Controlled Environments (PRINCE2), the Waterfall model and the Agile model are revealed. The strengths and weaknesses of each of these methodologies are identified in a public context. It is emphasized that the practice of the business sector in the usage of project methodologies cannot be automatically transferred to the public domain, but must consider political, managerial, and administrative aspects.

It is noted that the successful implementation of e-government projects depends on the approach, methods and tools of project management; monitoring and evaluation of egovernment projects; definition and management of the scope; project risks and mitigation, etc.

Projects should be managed on an ongoing basis when problems arise, and PMBOK should go beyond a structured and repetitive process in the manufacturing sector. The methodology of the waterfall provides for long time limits without flexibility in accepting requirements at later stages of development. A business user is not able to view the product unless it is fully developed. PRINCE2 focuses on projects where the beginning, middle and end are organized and controlled, with regular reviews of progress taking place as planned. Tracking is based on business criteria, flexible decision-making points, 
automatic management control of any deviations from the plan, involvement of management and stakeholders at the right time and place during the project, good communication channels. Agile is a set of flexible and easier methodologies that depend on principles such as time frame iterations, daily meetings, continuous improvement, etc.

The constructive experience of using different methodologies of project management in e-government of some developed countries, in particular Australia, the USA, Switzerland, etc. is outlined.

Keywords: methodology, project management, e-government, public administration, waterfall model, agile model, monitoring, risks.

Постановка проблеми. Результати фахових опитувань, проведених у різні періоди часу, свідчать про високий процент невдалих проєктів електронного уряду, особливо в країнах, що розвиваються [1]. Закономірно, це ставить під сумнів інвестування фінансових та людських ресурсів у відповідні проєкти.

Значну кількість проєктів електронного уряду спіткав повний або частковий провал. Дослідження показують, що близько 35\% проєктів у секторі електронного управління були повністю дискредитовані через те, що впровадження не було виконано або відмовило одразу після початку. 50\% проєктів електронного уряду були частково невдалими, оскільки визначені цілі не були досягнуті, або спочатку були успішними, а пізніше були невдалими. Лише близько 15\% - мали повний успіх для всіх зацікавлених сторін, i жодних несприятливих результатів. Завдяки громадянській орієнтації послуг, електронний уряд - це більше, ніж просто технологічна ініціатива, на відміну від типових IT-проєктів. Ключові бар'єри для успіху проєкту електронного уряду можна пов'язати 3 політичними, адміністративними, галузевими перепонами, а також кінцевими користувачами та громадянами [1]. Це складний зв'язок між зобов'язаннями зацікавлених сторін, структурованими державними процесами та інфраструктурними ресурсами.

Аналіз останніх досліджень та публікацій. Серед дослідників, які займаються вивченням різних методологій проєктного менеджменту та їх застосуванням у царині публічного управління, можна виділити Б. Астона, Д. Дріснака, А. Кларка, Д. Пірса, С. Фурлонга. Однак, напрацювання цих експертів стосуються переважно окремих методологій і не дають їх загального огляду.

Мета статті: розкрити зміст та особливості ключових методологій проєктного менеджменту в публічному управлінні.

Виклад основного матеріалу. За даними Інституту управління проєктами (PMI), успішна реалізація проєктів електронного урядування залежить від:

1) підходу, методів та інструментів управління проєктами;

2) моніторингу та оцінки проєктів електронного управління;

3) визначення та управління сферою застосування; 
4) ризиків проєкту та пом'якшення.

Згідно з дослідницьким опитуванням, проведеним Інститутом управління проєктами, виявлено, що уряд не може контролювати проєкти через відсутність відповідних інструментів та методів для виконання проєкту [1]. Немає єдиного інструменту для представлення комплексного уявлення про декілька проєктів 3 кількома постачальниками. Спеціальні завдання та зміна пріоритетів впливають на значну критичну діяльність. Виробник рішень керує термінами, але затримки можуть виникнути через процедури уряду. Окрім того, серед урядовців бракує тих, хто володіє знаннями з питань управління проєктами.

Найважливішою причиною $\epsilon$ те, що проєкти електронного уряду не відповідають жодним стандартизованим межам впровадження управління проєктами, а департаменти не усвідомлюють важливості цих стандартних меж. Часто для забезпечення успіху проєкту не вважається обов'язковим дотримуватися методології управління проєктами.

Моніторинг проєкту відбувається лише на засіданнях, а завдання визначаються на засіданнях керівного комітету замість заздалегідь розглянутих планів. Натомість, має бути повна прозорість плану, структури розподілу робіт та питань, що впливають на хід проєкту. Слід прийняти підхід, що грунтується на етапах, оцінюючи його на різних пунктах перевірки [1].

3 плином часу з'явилися різні методології управління проєктами 3 кращими практиками та еталонними стандартами, які були прийняті як у державному, так і в приватному секторах. Однією 3 прийнятих у всьому світі систем управління проєктами є Довідник з управління проєктами (РМBOK), опублікований PMI. Проєкти в контрольованих середовищах (PRINCE2) - це ще одна структура, розроблена Організацією урядової торгівлі (Великобританія), і прийнята урядом Великобританії як стандарт управління проєктами. Міжнародна асоціація управління проєктами (IPMA) - це ще одна методологія, яка надає стандарти для управління проєктами. Світовий банк, приміром, використовує підхід логічних рамок, який був розроблений Агентством США $з$ міжнародного розвитку (USAID) [1]. Існують деякі методології, розроблені постачальниками, такі як Microsoft Solutions Framework (MSF) та IBM Rational Unified Process (RUF), які є специфічними для кожного продукту. Деякі 3 найбільш часто використовуваних методологій управління проєктами в IT-секторі - це Agile, Scrum, Kanban, Scrumban, Lean, Extreme Programming (XP), Waterfall, PRINCE2, PMBOK тощо.

Інструменти та методи, що використовуються у корпоративному секторі, також можуть бути задіяні й у публічному, але їх слід налаштувати так, щоб вони враховували особливості державного сектору. Розглянемо більш предметно найбільш аплікативні у публічному вимірі методологіі.

Довідник з управління проєктами (РМВОК). 
Довідник з управління проєктами (РМBOK) базується на традиційних галузях промисловості та виробництва, розроблених Інститутом управління проєктами (PMI), які прийняті як глобальний стандарт управління проєктами. РМВОК - це офіційний документ, який визначає норми, методи, процеси та практику управління проєктами [2].

Що стосується електронного урядування, то вимогою $є$ управління різноманітними та суперечливими інтересами зацікавлених сторін у межах однієї структури управління проєктами. Додатки електронного управління переважно розробляються одним або кількома департаментами або центральними державними органами. Вони побудовані на їх унікальних законодавчих повноваженнях, підзвітності, процесах та потребах безпеки.

У більшості випадків вимоги користувача випливають з потреб громадянина. У всій методології РМВОК не наголошується на важливості перевірки чи перегляду вимог зацікавлених сторін та системних змін, які $є$ результатом збору початкових вимог. Вплив політичних інтересів може призвести до зміни фактичних вимог i, отже, вплинути на мету проєкту [3]. Доволі часто покрокове планування у традиційній моделі РМВОК не виконується так, як було розроблено. Традиційний підхід призводить до повільної розробки, коли обсяг може бути досягнутий, але не принести бізнесу користі [4].

Необхідно співвідносити інтереси зацікавлених сторін із вимогами щодо звітності, враховуючи зміну ступеня впливу. РМВОК не вирішує питань, пов'язаних зі «змішуванням» людей, процесів та технологій. РМВОК не зосереджується на перегляді бізнес-процесу, що $\epsilon$ результатом нового проєкту. "Прогресивна розробка" використовується для кращого розпізнавання ітераційного процесу розуміння вимог проєкту. РМВОК не розглядає вплив проєкту всередині організації чи на нові бізнес-процеси. Виникає необхідність керувати новими бізнеспроцесами, що є результатом реалізації нового проєкту. РМВОК можна розширити, включивши підходи до розвитку системи, що передбачають партнерство 3 зацікавленими сторонами та трансформаційні рішення.

Управління проєктами в електронному уряді включає багато департаментів, складну політику, процедури, нормативні акти та дані з широко розповсюдженою інформацією. Ніхто не має доступу до повної сукупності знань для реалізації проєкту. Не існує цілісного підходу до управління такими широко розповсюдженими державними даними та пошуку даних, які знаходяться в різних базах даних. Проєкти повинні керуватися постійно, коли виникають проблеми, а РМВОК має виходити за межі структурованого та повторюваного процесу у виробничому секторі. РМВОК не реалізує управління проєктами як потенційну рушійну силу з повноваженнями керівника проєкту, які практично не окреслені [3]. 
Модель «Водоспаду».

Ця методологія управління проєктами, орієнтована на програмне забезпечення, відповідає підходу «згори-вниз» до специфікації вимог, розробки/кодування системного проєктування, тестування, розгортання та обслуговування. Це структурований підхід з чітко визначеними діями та результатами в кінці кожної фази. Він охоплює стандартизацію процесів та зосереджується на технічній документації 3 чітко визначеним підходом до проєктування, розробки, впровадження та управління. Він зосереджується на аспекті забезпечення якості продукту з метою, щоб останній відповідав вимогам замовника від початку проєкту [5]. Життєвий цикл розвитку системи включає традиційні методи водоспаду, системний аналіз та методологію проєктування, життєвий цикл розвитку системи, раціональний уніфікований процес, модель швидкої розробки додатків, модель дизайну розвитку динамічних систем тощо [6].

Метод водоспаду - це найдавніший підхід у цій методології, в якій кожна діяльність ведеться як окрема послідовність і завершується перед початком наступної. Тут вимоги вважаються стабільними, а документація «уроків» проєкту допомагає у майбутніх проєктах [7]. Методологія водоспаду передбачає тривалі часові межі без гнучкості у прийнятті вимог на пізніх стадіях розвитку [8]. Бізнескористувач не має можливості переглянути продукт, якщо він повністю не розроблений. Повернення до попереднього етапу для вирішення проблеми $\epsilon$ порівняно складним, а будь-які зміни потрібно вносити на основі запиту на зміну 3 офіційними затвердженнями після перевірки його доцільності.

Проєкти в контрольованих середовищуах (PRINCE2).

PRINCE2 був створений у 1989 році і використовувався у проєктах уряду Великобританії. PRINCE2 - це підхід до управління проєктами, що базується на процесах, забезпечує простий у адаптуванні та масштабуванні метод для всіх видів проєктів. Визначаються цілі та заходи, які необхідно здійснити, і кожен процес має певні вхідні та вихідні результати [9].

Передбачено сім процесів:

- запуск проєкту;

- ініціювання проєкту;

- керування проєктом;

- контроль етапу;

- керування межами етапів;

- керування доставкою продукції;

- закриття проєкту.

У цілому, PRINCE2 націлений на проєкти, де початок, середина та кінець організовані та контролюються, регулярні огляди прогресу відбуваються відповідно до плану. Відстеження здійснюється на основі бізнес-критеріїв, гнучких пунктів 
прийняття рішень, автоматичного управлінського контролю за будь-якими відхиленнями від плану, залучення керівництва та зацікавлених сторін у потрібний час та місце під час проєкту, хороших каналів комунікації [10].

Проблеми з проєктами типу PRINCE - це:

1) жорсткі організації, що працюють у паралелі;

2) конкуренція за людські ресурси.

PRINCE2 та традиційні методології урядових IКТ-проєктів використовують добре відокремлену та добре структуровану організацію. Розробка або зміна ITпрограми можлива лише в тому випадку, коли іiі ініціює відділ-ініціатор. Проєктна організація працює незалежно, і остаточний проєкт виходить за межі, визначені відділом користувачів. Команда проєкту матиме двох керівників: керівника проєкту, який відповідає за виконання проєкту; керівника відділу користувачів. Це призводить до конфліктів у використанні ресурсів. У державному секторі менеджери не контролюють роботу установи. Зміни в урядовому законодавстві без попередньої консультації можуть вплинути на роботу проєкту.

Agile управління проєктами.

Agile, підхід спочатку розроблений для індустрії програмного забезпечення, був одним із нових методів, до яких урядові організації почали проявляти інтерес завдяки його підвищенній чуйності та співпраці. Уряди також прагнуть до більш широкого середовища співпраці та збільшення участі користувачів та внутрішньої співпраці. Agile - це набір гнучких та легших методологій, які залежать від таких принципів, як ітерації 3 часовими рамками, щоденні зустрічі, постійне вдосконалення тощо.

Різні гнучкі методи включають екстремальне програмування (XP), SCRUM, розробку за допомогою функцій, метод динамічних систем (DSDM), ощадливу розробку/управління. Вони об’єднані, оскільки, по суті, однакові.

Agile означає виконання проєкту меншими періодами, що триватимуть 2-4 тижні, після закінчення яких пропонується працездатне рішення, яке проходить ряд ітерацій, щоб включити всі вимоги.

Agile не складається 3 детальних специфікацій або вичерпного розкладу, але кінцевий продукт будується на основі спільних та ітераційних процесів, з постійним зворотним зв'язком від бізнес-користувачів [4]. Agile забезпечує більш тісну взаємодію з клієнтами та регулярний хід демонстрацій. Agile, зазвичай, включає невеликі проєктні групи, переважно менше 10 осіб, де часові межі вимірюються тижнями [4].

Деякі з ключових викликів, що стосуються масштабування Agile в уряді, включають багаторічні дорожні карти, управління, залежності між командами, наскрізну функціональність тощо.

Щоб Agile досяг успіху, партнер із державного сектору має зробити активний 
внесок у весь процес розвитку. Якщо Agile не реалізується 3 належним моніторингом, це може призвести до просто непродуктивного набору завдань [4]. Деякі з проблем, виявлених при впровадженні Agile в публічну організацію, пов'язані $з$ неадекватною документацією; переходом в управлінні від методології «водоспаду» до agile; фактом, що багатьом людям, окрім своїх звичних обов’язків, необхідно освоїти нові навички. Спритні практики вимагають постійного залучення, що іноді може бути складним. Що стосується інтерфейсів між програмними системами, які можуть бути не визначені на ранніх етапах гнучкої практики, впровадження може бути складним.

Узгодження змін у дизайні може вплинути на порядок впровадження. Якщо зацікавлені сторони знаходяться в різних географічних регіонах, співпраця може бути складною. Можливо, власнику продукту доведеться спілкуватися з кількома власниками бізнесу, і це створить залежність від цих зацікавлених сторін протягом усього проекту. Власники бізнес-продуктів, власники продуктів IKT, майстри scrum можуть заплутати команду. Іноді законодавство може перешкоджати відносинам між постачальником та організацією. Складність архітектури та систем програмного забезпечення $є$ складною у прийнятті, оскільки більшість систем включає кілька груп користувачів, кілька бекенд-систем, розроблених різними командами.

Наведемо кілька прикладів конструктивного використання вище проаналізованих методологій проєктного підходу у публічному управлінні та адмініструванні окремих розвинених країн світу. Так, департамент житловокомунального господарства США прийняв життєвий цикл, який слідує групам процесів керівництва РМВОК як заміну існуючого життєвого циклу розробки програмного забезпечення. Офіс управління проектами штату Нью-Йорк розробив Посібник 3 управління проєктами штату Нью-Йорк на основі РМВОК, співпрацюючи 3 PMI 3 усіх проєктів, включаючи проєкти IT та програмного забезпечення. Стандарт інформаційних технологій штату Нью-Йорк прийняв життєвий цикл розвитку системи («Водоспад») для організації діяльності з безпеки.

Урядовий функціональний стандарт, визначений Управлінням інфраструктури та проєктів уряду Великобританії, прийняв PRINCE2 i пізніше Agile у своїй діяльності з управління проєктами. Голландські проєкти електронного урядування використовують методологію PRINCE для управління проєктами. Швейцарська адміністрація прийняла методологію управління проєктами під назвою HERMES i зробила її обов'язковою для всіх державних проєктів [1].

Гнучка методологія використовується у наданні послуг в Австралійській державній службі, Австралійській податковій службі, Департаменті освіти, Національному регуляторі важких транспортних засобів. Вікторіанський уряд Австралії вважає, що важливіше налаштувати та використати вибрану методологію, 
що відповідає вимогам бізнесу, ніж вибрати правильну методологію управління проєктами [7].

Департамент Прем'єр-міністра та Кабінет міністрів Австралії рекомендує адаптувати інструменти з методології чи кількох методологій управління проєктами відповідно до вимог та бажаних результатів урядової ініціативи. Урядам необхідно розглянути можливість розробки індивідуальної основи управління проєктами 3 легко адаптованими інструментами та технологіями та зробити ії обов'язковою для виконання проєктів електронного управління.

Висновки. Методологія управління проєктами є обов'язковою умовою успіху будь-якого проєкту. Однак, вибір правильної методології є критичним, оскільки не всі методології відповідають усім проєктам. Вибір правильного методу залежить від таких чинників, як характер проєкту, час, вартість, обсяг, якість, участь зацікавлених сторін тощо. Методології управління проєктами часто зосереджуються на процедурах та процесах, а не на результатах та підзвітності. Жодна з методологій не надає керівнику проєктів трансформаційного електронного уряду інструментів, які дозволяють вирішити внутрішні проблеми, що впливають на реалізацію проєкту електронного уряду. Розширені методології повинні зосереджуватися на досягнутих результатах, а команда проєкту нести відповідальність за успіх чи невдачу проєкту [2]. Проєкти електронного уряду не слід розглядати як просте впровадження IT-систем в управління. Це поєднання трансформації урядових процесів з інноваціями та новітніми технологіями в межах оптимальних фондів. Вибір методології повинен грунтуватися на досягненні цієї трансформації, щоб забезпечити повне задоволення громадян.

\section{Лimepamypa:}

1. Thornton G. Project Management in e-Governance: Issues \& Challenges in navigating to the "New Normal". URL: https://www.pmi.org.in/downloads/pmi.nisc.egovernance.pdf.

2. PMI. Guide to the Project Management Body of Knowledge, (5th ed.). Project Management Institute.1, 2013.

3. Management Association, I. Project Management: Concepts, Methodologies, Tools, and Applications. IGI Global, 2016. P. 2119-2129.

4. Sills D., Miller W., Eggers W., O'Leary J. Agile in Government. URL: https://www2.deloitte.com/content/dam/insights/us/articles/3897_Agile-in government/DUP_Agile-inGovernment-series.pdf.

5. NISG. e-Governance Project Lifecycle. NISG. URL: https://meity.gov.in/writereaddata/files/eGovernance_Project_Lifecycle_Participant_Handbook-5Day_CourseV1_20412.pdf.

6. Saravanan K. Systems Development Methodology: Conceptual study. Indian Journal of Scientific Research, 2017. Vol. 14(1), P. 27-37.

7. Victorian Government CIO Council. Selecting a project management methodology, 2013. Vol. 4-5.

8. Clarke A. Digital Government Units: What Are They, and What Do They Mean for Digital Era Public Management Renewal? International Public Management Journal, 2019. P. 1-31. 
9. Group I. PRINCE2 Information \& PRINCE2 Courses for Project Managers provided by ILX Group UK. Prince2.com. URL: https://www.prince2.com/uk/prince2-processes.

10. Pearce D. Government IT projects. London: Parliamentary Office of Science and Technology, 2003. P. 2-27.

\section{References:}

1. Thornton, G. (2011). Project Management in e-Governance: Issues \& Challenges in navigating to the "New Normal". Retrieved from https://www.pmi.org.in/downloads/pmi.nisc.egovernance.pdf.

2. PMI. (2013). Guide to the Project Management Body of Knowledge, (5th ed.). Project Management Institute.1.

3. Management Association, I. (2016). Project Management: Concepts, Methodologies, Tools, and Applications. IGI Global. P. 2119-2129.

4. Sills, D., Miller, W., Eggers, W., \& O’Leary, J. (2017). Agile in Government. Retrieved from https://www2.deloitte.com/content/dam/insights/us/articles/3897_Agile-in government/DUP_Agile-inGovernment-series.pdf.

5. NISG. (2012). e-Governance Project Lifecycle. NISG. Retrieved from https://meity.gov.in/writereaddata/files/e-Governance_Project_Lifecycle_Participant_Handbook-5Day_ CourseV1_20412.pdf.

6. Saravanan, K. (2017). Systems Development Methodology: Conceptual study. Indian Journal of Scientific Research, Vol. 14(1), P. 27-37.

7. Victorian Government CIO Council. (2013). Selecting a project management methodology, Vol. 4-5.

8. Clarke, A. (2019). Digital Government Units: What Are They, and What Do They Mean for Digital Era Public Management Renewal? International Public Management Journal. P. 1-31.

9. Group, I. (2020). PRINCE2 Information \& PRINCE2 Courses for Project Managers provided by ILX Group UK. Prince2.com. Retrieved from https://www.prince2.com/uk/prince2-processes.

10. Pearce, D. (2003). Government IT projects. London: Parliamentary Office of Science and Technology. P. 2-27. 